\title{
STRUKTÚRÁK REGIONÁLIS EGYENLŐTLENSÉGEI
}

\author{
(Regional Structural Inequalities)
}

\section{CZIRFUSZ MÁRTON}

Kulcsszavak:

struktúravizsgálat gazdaságszerkezet regionális különbségek Williamson-hipotézis

A területi kutatások elkülöníthetỏ csoportját alkotják a szerkezetvizsgálatok. A tanulmány a struktúra fogalmi meghatározási lehetőségei mellett részletesen foglalkozik a vizsgálati módszerekkel. Magyarországi és európai példákon keresztül mutatja be a vektorszemléletü módszer elönyeit és hátrányait. Egy ötvenkét országra kiterjedö empirikus vizsgálat a Williamson-hipotézis kiterjeszthetôségét támasztja alá az országos fejlettségi szint és a regionális gazdaságszerkezeti egyenlötlenségek kapcsolatára.

\section{Bevezetés}

Tulajdonképp minden olyan esetben, amikor valamely területegységre vonatkozó adattal dolgozunk, az adott területre jellemzö strukturális mutatókat használunk. Egy terület, ország, régió, település egyedisége ugyanis a különbözö jelzöszámok és számokkal nem kifejezhetỏ tulajdonságok, jellemzők összességével, azok egymáshoz való viszonyával, vagyis az általuk meghatározott szerkezettel modellezhető és azonosítható. Ezen általános jelenség ellenére a területi kutatásoknak - de akár ide sorolhatjuk a közgazdaságtani kutatások egy részét is - elkülöníthető csoportját képezik azok, melyek kifejezetten a szerkezetre, vagy annak változására összpontosítanak.

A hétköznapokban is sokszor használt szerkezet fogalmához többféle tartalom köthetö. A tanulmány első része ezen meghatározások közül emeli ki a területi kutatásokhoz kapcsolódó legfontosabbakat és mutatja be azok jellemzőit. Egy területegység struktúrájának vizsgálatakor a legnagyobb vizsgálati nehézséget a szerkezet összetettsége okozza, amely mérési és módszertani problémákat vet fel. Ezen a következỏ részben tárgyalandó - kérdések fokozottan jelentkeznek, ha a vizsgált témakör a szerkezet több dimenzióját érinti.

A struktúravizsgálatok esetében különböző megközelítési módokhoz különbözö módszertani háttér tartozik. Legtöbb esetben egyszerủbb vagy összetettebb kvantitatív módszerek is alkalmazásra kerülnek. A tanulmányban a sok eljárás közül bővebben bemutatom a vektorszemléletủ megközelítésmódból adódó jelzőszámokat, azok jellegzetességeit, előnyeit és hátrányait.

A regionális tudomány egyik alapösszefüggésévé vált a Williamson-Kuznetshipotézis, amely empirikus vizsgálatok alapján az országok gazdasági fejlettsége és regionális fejlettségi tagoltsága között egy fordított-U görbét adó összefüggést feltételezett (Williamson 1965; Nemes Nagy 1987). Analóg módon vizsgálható a gazdasági fejlettség és a regionális gazdaságszerkezeti heterogenitás összefüggése is a 
világ országaiban. A fordított-U egyes kontinensek vagy nagyrégiók vizsgálata esetén és elméleti úton közelítve ebben a módosított kérdésfeltevésben is megalapozott hipotézisként van jelen a szakirodalomban (Junius 1996; Aiginger 1999; Wacziarg 2004). Empirikus vizsgálatomban a világ 52 országára kiterjedően hasonlítom össze a GDP ágazati szerkezetével számszerüsített gazdasági szerkezet regionális tagoltsága és az országos gazdasági fejlettségi szint (egy före jutó GDP) összefüggését. Ezen belül külön megvizsgálom az egyébként kiegyenlítettnek mondható Európában tapasztalható különbségeket, trendeket, amelyek a gazdaságszerkezeti egyenlőtlenségek okainak összetettségét és a magyarázatokban bizonyos regionális tudományi és társadalomföldrajzi modellek alkalmazhatóságát támasztják alá.

\section{Szerkezet: egy fogalom meghatározási lehetöségei nem csak a területi kutatásokban}

A szerkezet (struktứra) a hétköznapokban leginkább az elrendezödés és a rendezettség fogalmaihoz kapcsolódva jelenik meg, és általában a külső térben is megjelenő szerkezetet takar.

„Struktúra (latin: structura) szó szerint annyit jelent, mint: felépítés, felépítési mód, belső rend(ezettség), tagolás/tagoltság. Közelebbröl nézve a szerkezet lényege egyrészt abban nyilvánul meg, hogy az egyes részek a feléjuk rendelt egésszel és egymással milyen módon vannak összekapcsolódva (kvalitatív szempont), másrészt hogy mekkora az egyes részek mérete az egészhez képest (kvantitatív szempont). Általánosságban a struktúra úgy definiálható, mint az egésznek részei, amelyek az egésszel és egymással meghatározott minőségi és mennyiségi viszonyban állnak." (Peters 1988, 19). Hasonló módon vélekedik a struktúráról Hjalmarsson: „a struktúra olyan viszonyok rendszere, melyek az egység részei között érvényesülnek" (Hjalmarsson 1973; idézi Vikström 2001, 5). Mindkét definícióban közös, hogy alkotóelemekkel és köztük levő kapcsolatokkal azonosítják a szerkezetet. A szerkezet összetettsége, sokdimenziós és sokmutatós jellege területi kutatásokban elméleti és módszertani-mérési nehézségeket okoz. Emellett a struktúra összetettsége alapján különíthetjük el a területi szerkezetvizsgálatok két csoportját is.

A területi kutatásokban a mérési nehézségek áthidalására két utat választhat a kutató. Az egyik az egyszerúsítés, vagyis egy vagy néhány tipikus indikátor vagy összefüggés kiválasztása és elemzése. A másik lehetőség az átfogó áttekintés, a sok jellemző teljességének vizsgálata, vagy közülük kevesebb jellemző ismérv kialakítása (Rechnitzer szerk. 1994). Elöbbi esetben a vizsgált kérdések is könnyebben értelmezhetőek, módszertanilag pedig egyszerübb matematikai-statisztikai eljárások alkalmazhatóak. A második lehetőség tágabb struktúraértelmezésekor összetettebb, sokdimenziós módszerek (például faktoranalízis) kerülnek előtérbe, hiszen az egyes strukturális dimenzióknak a legtöbb esetben eltérő a mértékegysége. Ugyanígy hangsúlyossá válnak az idiografikus megközelítések, a verbális modellek, azaz a vizsgált térség egyediségének megragadása. Ezt az elkülönítést szemléltethetjük a földrajzi adatmátrixon, illetve sajátos földrajzi megközelítésmódokat - kérdésfeltevéseket 
társíthatunk hozzájuk. „A földrajztudományi kutatómunka különböző formái az adat-mátrixon végzett eltérö műveletekre vezethetők vissza. Az ágazati geográfia területi egységek széles skáláján mozog, de a funkcionálisan összefüggő változók szük körére terjed, és így alapját a mátrix sor-vektorai képezik. Ezzel szemben a regionális földrajz egy-egy területi egység lényeges, sajátos belső összefüggéseit igyekszik megragadni, tehát csupán egy vagy néhány oszlop-vektorral, de a változók rendkívül széles körével dolgozik. Az oszlop-vektorok párhuzamos vizsgálata vezet el az összehasonlító regionális földrajzhoz, a teljes adat-mátrixon belül elkülöníthető boxok (szub-mátrixok) pedig valamely körülhatárolt térség ágazati tanulmányozásának bázisát képezik. Harmadik dimenzió bekapcsolásával az időben lezajló változások, folyamatok szintén bevonhatók a kutatás körébe." (Probáld 1995). Mivel a strukturális mutatók területi összehasonlítása a fenti terminológiát használva egyaránt ágazati és regionális (földrajzi) probléma, ezért ez a kutatási irány többnyire a szubmátrixokkal dolgozik. De különbségeket találhatunk a módszerek között abban, hogy az összes sort és oszlopot, vagy csak néhányat használják-e, vannak-e olyan oszlop/sortulajdonságok, melyek az adott módszer használatának előfeltételei, illetve hogy a módszer alkalmazása révén létrejönnek-e (többnyire igen) új sorok, oszlopok vagy mátrixelemek. Szintén elkülöníthetővé válnak a statikus és a dinamikus vizsgálatok.

\section{Egyszerübb és összetettebb vizsgálati módszerek}

A struktúravizsgálatokban használt legegyszerübb kvantitatív módszer az ágazati megoszlási viszonyszámok összehasonlítása. Egydimenziós struktúrák időbeli összehasonlításakor az egyes ágazatok-szektorok részesedésében végbement változás összege is egy dinamikát jelző mutatóként értelmezhetö (Liikanen 1999). Ennek az eljárásnak a hátránya többek között, hogy nem fejezi ki a változás irányát, így periodikus átalakulások esetében folyamatos változást mutat.

Szerkezetvizsgálatokban a kutatók nagyon gyakran alkalmaznak ágazati egyenlötlenségi mutatókat. Ezek a területi egyenlötlenségi mutatók (Hoover-index, szórás, Gini-koefficiens stb.) analógiájára az egyes vizsgált területegységek ágazati sokszínüségét számszerüsítik. Míg a területi egyenlötlenségi mutatók a koncentráció mértékére adnak információt, az ágazati egyenlőtlenségi mutatók a specializáltság szintjét mutatják. A vizsgálati szempontok viszonylag rugalmasan változtathatóak, a mutatók idősoros elemzésekre is alkalmasak, melyre a szakirodalomban számos példát találhatunk (Kiss 1998; Jeney-Szabó 2001; Aiginger-Davies 2004; Bickenbach-Bode 2006).

A vizsgált területegységek a szerkezeti összetevők és jellemzők belsö tereiben különbözö helyzetet foglalnak el, amely helyzetek részben számszerüsíthetőek is. Ez módszertanilag az n-dimenziós távolság meghatározásával történhet. Az eljárás egyrészt az ágazati egyenlőtlenségi mutatókhoz hasonlóan, a késöbb bemutatandó vektorszemlélettel szemben a struktúrák belső szerkezetének mérésére szolgál, és nem két szerkezet közvetlen összevetésére. Másrészt használható többdimenziós 
struktúrák egy számmal való jellemzésére is, ha az egyes mutatókat előbb standardizálással vagy normalizálással közös nevezöre hoztuk. Ekkor abból a hipotézisból indulunk ki, hogy a szerkezet ugyan komplex, de mégis megfogalmazható, elhatárolható valami, amely esetében értelmezhetö az, hogy két megfigyelési egység szerkezetileg hasonló vagy különbözö; azaz közel, vagy távol van egymáshoz képest. (Nemes Nagy 1998; Rechnitzer szerk. 1994).

A belső térbeli távolságon és a dimenziócsökkentésen alapuló legösszetettebb szerkezetvizsgálati módszer a faktoranalízis. Az ágazati egyenlótlenségi mutatókhoz hasonlóan itt is a területi adatmátrix oszlopainak számát csökkentjük, azonban nem feltétlenül egyre, hanem többre (de mindenképp az eredeti oszlopszám töredékére). Különbség még, hogy az információtömörítés nem kizárólag a sorok belsö szerkezetéből adódik, hanem abban az egész mátrix szerkezete leképezödik. Az így képzett mutatószámok azonban a módszer alkalmazása közbeni absztrakció miatt nem biztos, hogy könnyen értelmezhetók.

A szerkezeti jellemzök vizsgálatának más szempontú, földrajzi tartalommal is inkább rendelkező módszere a hatásarány-elemzés vagy shift-share analízis. A módszert legtöbbször dinamikus vizsgálatokra használják. Alkalmazásának jelentős korlátokat szab, hogy a területi adatmátrix soraiban és oszlopaiban hasonló számú elemnek kell lennie, valamint hogy a finomabb, részletesebb ágazati felosztás az analízis eredményeiben az ágazati tényező nagyságának növekedésével és a regionális tényező jelentöségének csökkenésével jár (Richardson 1978).

\section{A vektorszemléletü megközelítés}

A vektorszemléletü megközelítés kiküszöböli számos elöbbi struktúravizsgálati módszer gyengéjét (például a korábban említett mutatószámok nem változatlanok azokban az esetekben, ha az egyes összetevök ugyanolyan ütemben változnak, tehát ha a növekedést nem kíséri tényleges struktúraváltozás - Moore 1978). A módszer elsỏ alkalmazása V. V. Koszov nevéhez füződik az 1960-as évek elején (Koszov 1963; idézi Frigyes 2000). Alapötlete az, hogy az n számú strukturális összetevőhöz hozzárendel egy n-dimenziós strukturális vektort (két dimenzióban szemléltetve lásd az 1. ábrán). Két ilyen struktúravektor ( $\overrightarrow{O P}$ és $\overrightarrow{O Q}$ ) közötti szerkezeti eltérés számszerüsítésére két mérőszám is alkalmas:

- a két strukturális vektor hajlásszöge $(\Theta)$, vagy annak koszinusza: $\cos \Theta=\frac{(\overrightarrow{O P} \cdot \overrightarrow{O Q})}{|\overrightarrow{O P}| \cdot|\overrightarrow{O Q}|}$

- két, egységnyi hosszúságúra normált strukturális vektor távolsága: $d(\overrightarrow{O P}, \overrightarrow{O Q})=\sqrt{\sum_{i=1}^{n}\left(\frac{O P_{i}}{|\overrightarrow{O P}|}-\frac{O Q_{i}}{|\overrightarrow{O Q}|}\right)^{2}}$, ahol $0 \leq d \leq \sqrt{2}$ (Moore 1978). 
A strukturális közelséget kifejezö koszinusz nem ismeretlen az általános statisztikában. Belátható ugyanis, hogy a lineáris kapcsolatok szorosságát kimutató korrelációs együttható is a megfigyelt két adathalmaz (vektor) a vártható értékkel csökkentett értékeiböl képzett vektor közötti hajlásszög koszinusza (Frigyes 2000).

A két fenti mutatószám eleget tesz a strukturális eltérés méröszámával szemben elvárt matematikai feltételeknek, azaz:

- szimmetria: A és B adathalmazok között teljesül, hogy $\mathrm{d}(\mathrm{A}, \mathrm{B})=\mathrm{d}(\mathrm{B}, \mathrm{A})$;

- nem-negativitás: $\mathrm{d}(\mathrm{A}, \mathrm{B})=0$ csak akkor teljesül, ha $\mathrm{A}=\mathrm{cB}$, ahol $\mathrm{c}>0$ konstans,

- háromszög-egyenlótlenség: A, B, C eltérésmutatóira teljesül a $\mathrm{d}(\mathrm{A}, \mathrm{B})+\mathrm{d}(\mathrm{B}, \mathrm{C}) \geq \mathrm{d}(\mathrm{A}, \mathrm{C})$ összefüggés (Frigyes 2000).

A két struktúravektor által bezárt szög több, némely esetben hátrányos tulajdonsággal bír. Egyrészt a struktúraváltozást mutató szögek nem összeadhatók, mivel a változás az n-dimenziós térben zajlik. Másrészt a módszer nem ad tájékoztatást a strukturális eltérés irányáról sem.

\section{1. ÁBRA}

A vektorszemléletü megközelités értelmezése két dimenzióban (The Two-dimensional Interpretation of the Vectorial Inequality)

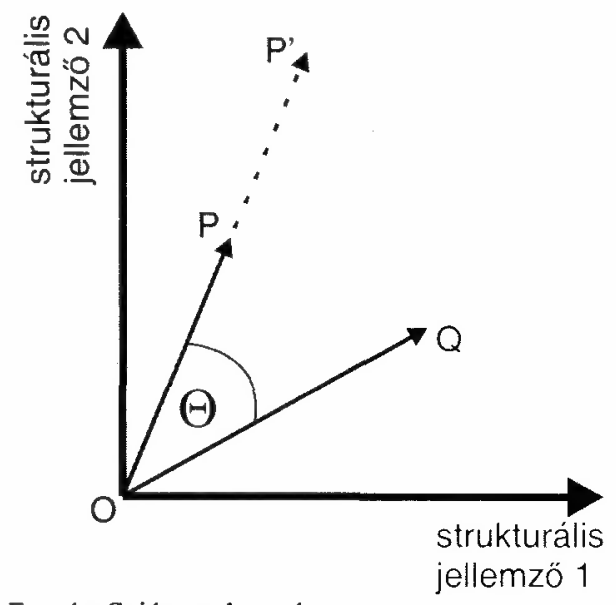

Forrás: Saját szerkesztés.

A módszer egyaránt alkalmazható statikus és dinamikus megközelítésben. Statikus vizsgálatban például két területegység ágazati GDP-szerkezetét hasonlíthatjuk össze - erre látunk majd példát a következőkben. Az időbeli összehasonlítások esetén alkalmazható két eljárás a bázis- és a láncindex logikáján alapul. A mindig az előző év vektorához való viszonyítás a rövid távú elmozdulások vizsgálatára alkalmas, de a hosszú távúakra (föleg a közvetlenül egymás utáni, ellentétes irányba mutató struktúraváltozások analizálására) kevésbé, mert az egymás utáni években történő változások nem feltétlenül mutatnak egy irányba, vagyis az évröl évre történö elmozdulások nem adhatók össze. A másik lehetőség egy adott évhez való viszonyítás, ekkor a kezdő vagy az utolsó időpontot érdemes választani, mert közbenső év 
választása esetén az eredményül kapott szögek nemnegatív voltából adódóan egy V-alakú görbét kapunk, amit nehéz értelmezni (Vikström 2001).

\section{A vektorszemléletü megközelítés néhány további sajátossága magyar- országi példa alapján}

A vektoros módszer további két sajátossága, hogy erősen specializációérzékeny, illetve, hogy ennek következtében a területi és az ágazati felbontás változásakor viszonylag eltérỏ eredményeket adhat. Ezen tulajdonságokat részletesebben Magyarország megyéinek 2004-es ágazati bruttó hozzáadott értéke alapján vizsgálom ( $K S H$ 2006).

Az egyes megyék bruttó ágazati hozzáadott értékét kétféle részletezettségü felosztásban vizsgáltam: egyrészt a három összevont nemzetgazdasági ág (mezőgazdaság, ipar, szolgáltatások), másrészt a 13 gazdasági ág esetében mértem a megyék országos szerkezettől való távolságát.

A megyék gazdasági szerkezetének átlagos eltérése (súlyozatlan átlag) az országostól a részletesebb felbontásban a háromszektoros felosztásnak közel kétszerese (17,15 fok, illetve 8,86 fok). Ez a jelenség egyáltalán nem meglepö, hiszen a területi kutatásokban közismert aggregációs-dezaggregációs hatás (vagyis hogy alacsonyabb területi szinten az egyenlötlenségek magasabbak) ágazati megfelelöjéröl van szó. A kétféle felbontásban mért megyei eltérések egymással szoros kapcsolatban vannak (a lineáris korrelációs együttható 0,78 ), de azonosíthatóvá válnak a trendtöl nagymértékben eltéró megyék is (2. ábra).

$\mathrm{Az}$ országos szerkezethez 2004-ben legközelebb Nógrád és Veszprém állt a két felbontás alapján. A skála másik végén az 1990-es évek közepétől ipari alapú dinamikát felmutató térségek (Vas, Fejér, Györ-Moson-Sopron és Komárom-Esztergom) találhatóak. Közülük is kiemelkedik Komárom-Esztergom, ahol az ipar összevont nemzetgazdasági ág részesedése az értéktermelésböl 57,7\% az országos 30,9\%-kal szemben (ebből a feldolgozóipar és a bányászat $51 \%$ az országos 22,7\%-kal szemben). Az egyik, vagy másik felbontás alapján kiugró megyék Tolna, Somogy és Veszprém; utóbbiban a 3 gazdasági ág alapján az eltérés sokkal nagyobb, mint a 13 ág alapján. Az elöbbi kettőben a két felbontás közötti különbség jórészt statisztikai hatásból adódik. Tolna megyében a Paksi Atomerömü tevékenysége révén a villamosenergia-, gáz, gőz- és vízellátás magas részesedése (14\% az országos 3,1\%-kal szemben) ellensúlyozza az alacsony feldolgozóipari és bányászati részesedést, így az ipar egészére egy átlagos értéktermelésből való részesedést kapunk - ezért a 3 ág esetében mért kis távolság. Somogyban a közigazgatás és a szálláshely-szolgáltatás, vendéglátás ágakban magasabb az értéktermelési arány az országosnál, ám ez a szolgáltatásokat egészében vizsgálva sem ad Tolnáéhoz hasonlóan nagy eltérést.

Magyarország esetében a regionális felbontás változtatása nem érinti jelentősebb mértékben az összefüggéseket. A regionális szintet vizsgálva az átlagos eltérés $(8,79$ fok a 3 gazdasági ágat és 16,28 fok a 13 gazdasági ágat tekintve) némileg csökken a megyéknél tapasztaltakhoz képest, a két ágazati felbontás közötti korrelációs 
együttható értéke pedig magas maradt $(0,87)$. Mindez egyben egy általánosabb területi fejlődési irányzatot is igazol: az egyazon régiókba tartozó (sorolt) megyék gazdaságszerkezeti hasonulását, a regionális szerkezeti kohézió meglétét.

\section{2. ÁBRA}

A magyar megyék gazdasági szerkezetének eltérése az országostól kétféle ágazati felbontásban a bruttó hozzáadott érték alapján (2004)

The Structural Heterogenity of GDP in Hungarian Counties, on two Agregational Level of Industrial Branches (2004)

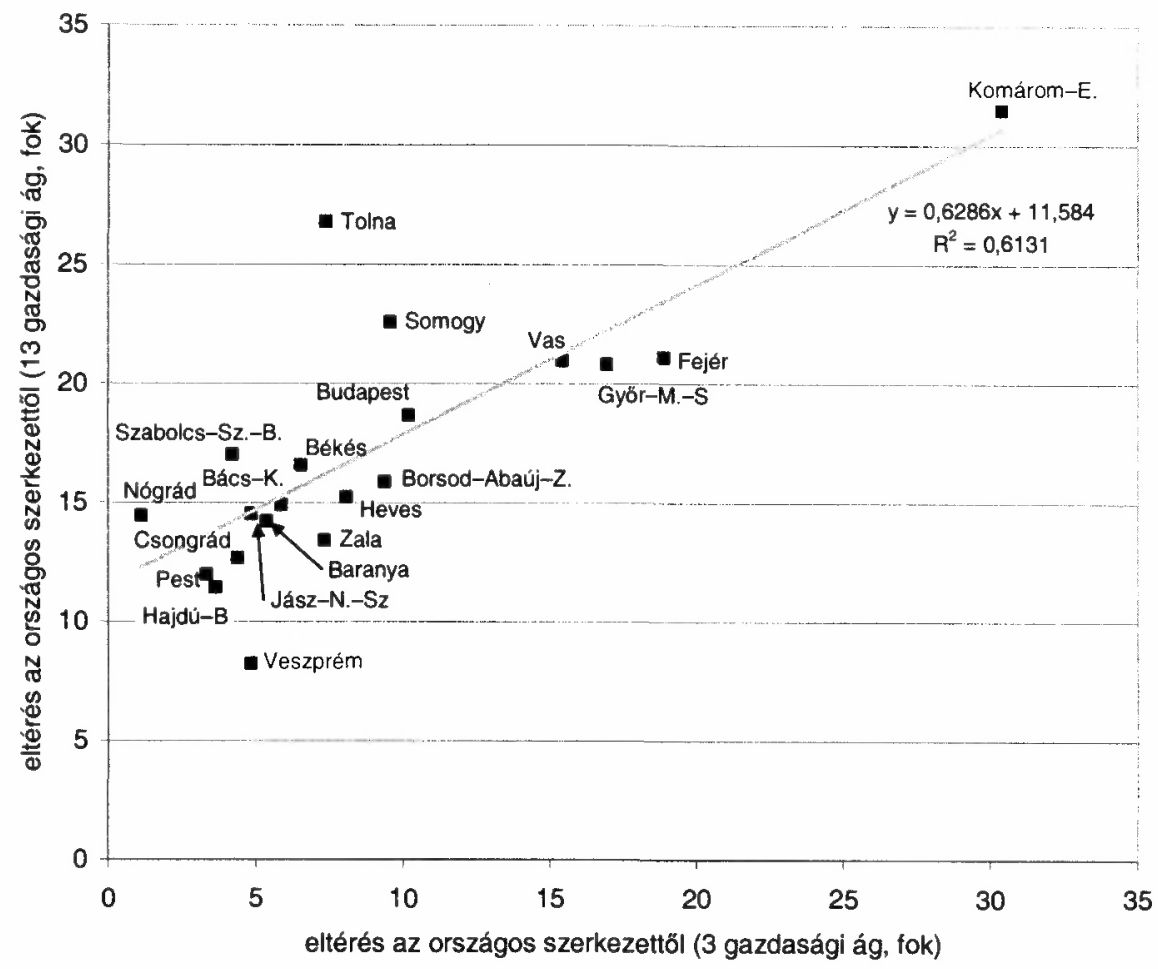

Forrás: KSH 2006 alapján saját számítások.

\section{Európa: a föbb tendenciák regionális szinten}

A vektoros módszerrel vizsgáltam az európai régiók gazdaságszerkezeti eltéréseit és ezek változását. A választott indikátor a NUTS3-régiók 3 összevont gazdasági ágra (mezőgazdaság, ipar, szolgáltatások) bontott bruttó hozzáadott értéke. Az adatokat a 27 régi-új tagállamra és Horvátországra a homogén EUROSTATadatbázisból nyertem, a gazdaságszerkezeti eltéréseket pedig a mindenkori európai átlagtól (EU-25), illetve az országok heterogenitásának mérése esetén az országos szerkezettól való fokokban mért eltéréssel azonosítottam. 
$\mathrm{Az}$ adatokat térképezve (3. ábra) három fö megállapítást tehetünk. Egyrészt a kirajzolódó térszerkezet rendkívül mozaikos, amelyet erösít az is, hogy a módszer nem mutatja az eltérés irányát (vagyis két azonos fokértékkel rendelkezö régió rendkívül különbözö gazdaságszerkezettel rendelkezhet). A másik, hogy az országhatárok mentén kirajzolódó fejlettségi törések sok esetben gazdaságszerkezeti eltéréssel párosulnak (mint Csehország nyugati határán vagy a magyar-román határon): az alacsonyabb fejlettségi szint nagyobb gazdaságszerkezeti eltéréssel jár. A harmadik megállapítás, hogy az európai értelemben vett földrajzi periférián (Baltikum, Románia, Bulgária, Görögország, Portugália egy része, Dél-Î́rország) általában magasabbak a regionális szintủ eltérések.

\section{3. ÁBRA}

Az európai régiók gazdaságszerkezetének eltérése az EU-25-ök átlagától (NUTS3 szinten, 2002)

(Structural Heterogenity of Regional Economies in the EU25 (2002, NUTS3, GDP-structure)

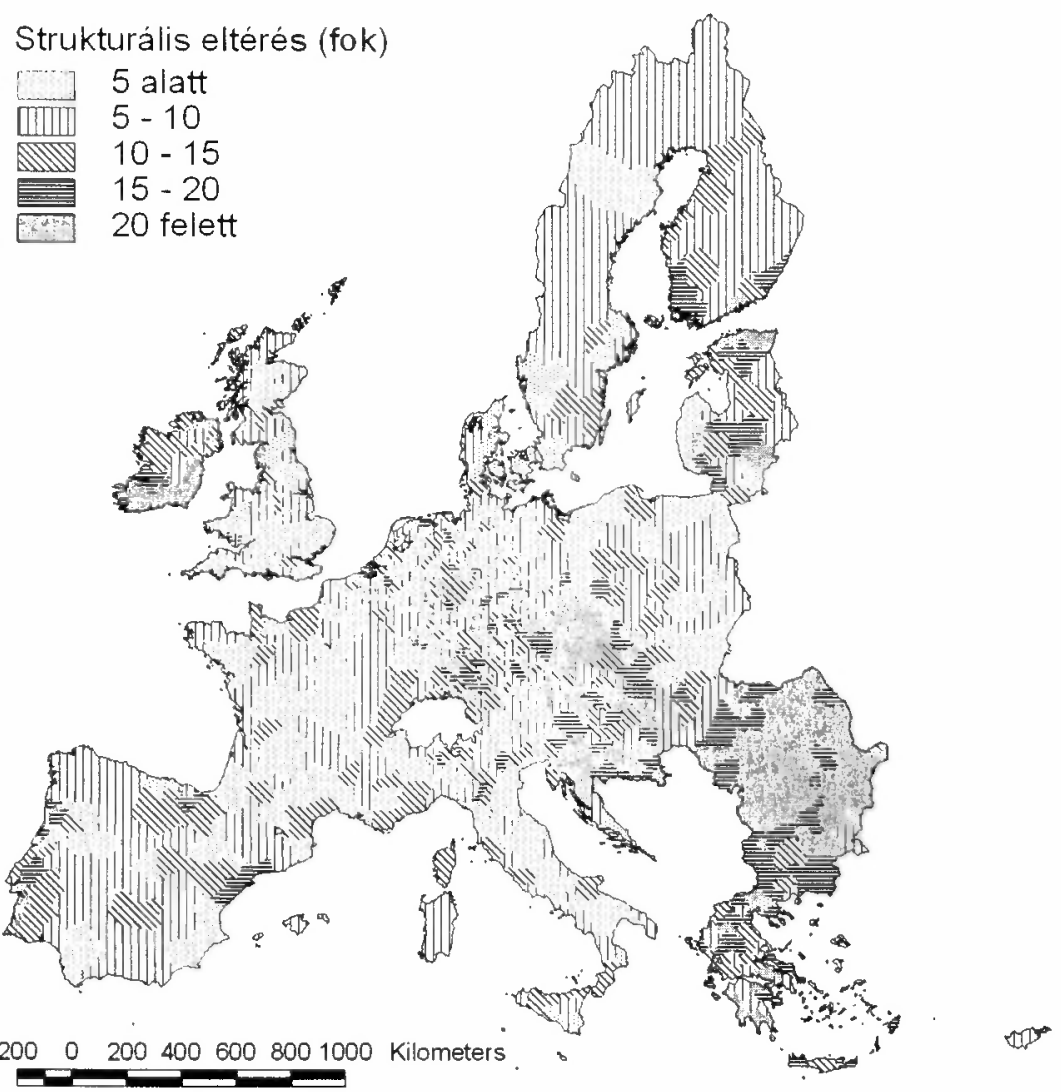

Forrás: EUROSTAT Regio adatbázis alapján saját számítások és szerkesztés. 
Az okokat vizsgálva három tényezőt emelhetünk ki. A homogén földrajzi adottságok gazdaságszerkezeti homogenitást is jelentenek: Dánia a regionálisan legkiegyenlítettebbnek mondható ország. A másik, hogy a gazdasági szerkezetváltozás növeli a regionális gazdaságszerkezeti különbségeket, mivel jellemzően nem minden régióban egyszerre megy végbe, hanem szelektíven; mégha elöbb-utóbb az ország jelentösebb részét el is éri. Ezt tapasztalhatjuk a 12 új EU-tagállam legtöbbjében, Portugáliában vagy Írországban. Magyarországon az 1995 és 2003 közötti idősort vizsgálva azt láthatjuk, hogy a mindenkori ipari sikermegyék egyikének gazdaságszerkezete tért el legjobban az Uniós átlagtól: 1995-96-ban Vas, 1997-2001-ig Fejér, 2002-2003-ban Komárom-Esztergom megyék, de Györ-Moson-Sopron is viszonylag magas fokokban mért eltéréssel rendelkezett. A harmadik fontos megállapítás, amely a vektorszemléletü megközelítés - a többi nem térparaméteres elemzési eljáráshoz hasonló - egyik gyengeségét jelzi, hogy az eredmények erősen függenek a térfelosztás módjától. A nagy európai országokban, amelyekben városrégiók önálló egységként nem léteznek - mint Franciaországban, Spanyolországban és részben Lengyelországban - az országos gazdaságszerkezettől való átlagos eltérés kisebb, mint például Németországban, ahol a közepes méretü városok is önálló NUTS3-as régiót képeznek. Lengyelország kiegyenlítettségében más tényezők többek között viszonylagos fejlettségbeli lemaradása - is szerepet játszhatnak, melyeket a következöekben vizsgálok.

$\mathrm{Az}$ egyes országokon belül az európai átlagtól legeltérőbb régiók mélyebb összefüggéseket rejtenek és különböző országcsoportokat jelölnek ki. A legfejlettebb országokban a fövárosi, szolgáltatások által meghatározott régiók térnek el legjobban az átlagos európai struktúrától, mint Párizs vagy Koppenhága esetében. Hasonló volt a helyzet Szlovéniában a vizsgált időpont kezdetétöl, 1995-től 2000-ig. Ezzel szemben a felzárkózó országokban a fövárosi térségek a ,legeurópaibbak”, mint azt Szófia, Bukarest, Prága, Pozsony, Vilnius, Tallinn vagy a kissé ebböl a körből kilógó Helsinki és Dublin esetében több vizsgált évben is tapasstalhatjuk. Az ipari központok magas eltérése sok európai országban mondható tipikusnak, ez a helyzet többek között Wolfsburgban (az ipar részesedése a Volkswagen-autógyárnak köszönhetően $77 \%$ a bruttó hozzáadott értékből), Ausztriában Steyr-Kirchdorf régióban (amely a linzi nehézipari körzetet foglalja rnagában) vagy Magyarország esetében. A két legújabban csatlakozott tagállam, Románia és Bulgária esetében periferikus helyzetü mezögazdasági dominanciájú térségek térnek el leginkább az európai átlagszerkezettől.

\section{Specializált térségek egy lehatárolási módszere a gazdasági szerkezet alapján Európában}

A vektorszemléletủ megközelítést egy fejezet erejéig félretéve a következőekben a gazdasági szerkezet alapján specializált régiók meghatározásának egy módszerét mutatom be. Egyúttal példát is hozok a térparaméteres elemzési eljárások egyikének erre a kérdéskörre való alkalmazására - így részben kiküszöbölve az elöbbiekben megemlített hiányosságokat. 


\section{4. ÁBRA}

A specializáció térbeli koncentráltsága Európában NUTS3-szinten (2002)

(Concentration of Regional Specialisation in the EU25 (2003, NUTS3)

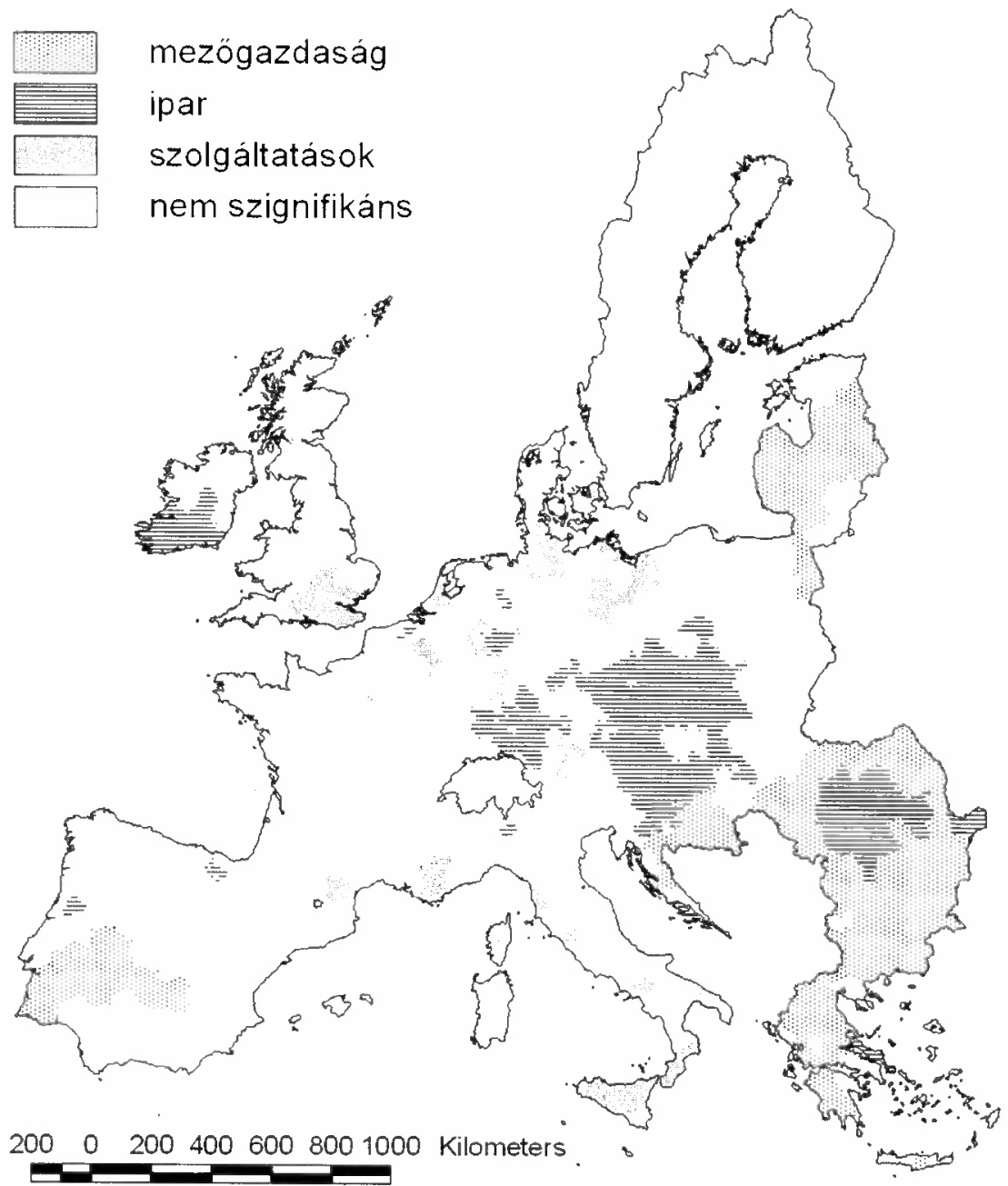

Forrás: EUROSTAT Regio adatbázisa alapján saját számítások és szerkesztés.

A 4. ábra három NUTS3-szinten végzett területi autokorrelációs vizsgálat egyesített ábrázolását mutatja. Mezőgazdasági, ipari, illetve szolgáltatási régiónak minősül egy térség, ha az adott szektor részaránya a bruttó hozzáadott értéken belül 95\%-os szignifikanciaszinten a régióban és szomszédjaiban is európai összehasonlításban magas (azaz a lokális autokorreláltság alapján a magas-magas kategóriába sorolható). Jól látható, hogy nagyobb mezőgazdasági térségek csak a földrajzi perifériákon rajzolódnak ki (a Baltikumtól a Balkánon át az Ibériai-félszigetig). Az ipari tevékenységeknek egy markáns centruma található Közép-Európában, ahol a fövárosi 
régiók (és a módszerből adódóan szomszédjaik) kivételével az ipari részesedés a bruttó hozzáadott értékből mindegyik régióban magas. Hasonló a helyzet DélÍrországban és Romániában nagyjából az Erdélyi-medence területén. A szolgáltató tevékenységekröl köztudott, hogy leginkább a városhierarchia mentén koncentrálódnak, ennek megfelelöen a hangsúlyosan tercier szektorú térségek szétszórtan találhatóak, két kivételtỏl, a Londoni-medencétỏl és egy dél-olasz turizmus dominálta térségtől eltekintve. Mindenképpen érdekes, hogy a módszer alapján nem rajzolódik ki az európai térszerkezeti modellek (például „kék banán”, Pentagon) egyike sem.

A módszer természetesen csak egy lehetőséget mutat be a specializált régiók lehatárolására, ám mindenképpen egy figyelembe vehető vizsgálati szempontot jelenthet.

\section{A Williamson-hipotézis kiterjesztése: fejlettségi szint és gazdaság- szerkezeti heterogenitás}

A Williamson-hipotézis a gazdasági fejlettség és a regionális fejlettségi különbségekben empirikus vizsgálatok alapján egy fordított-U alakú görbét adó összefüggést feltételezett. Ez az összefüggés az országok gazdasági specializációjában és a gazdasági tevékenységek koncentrációjában is fennáll, mint azt több empirikus vizsgálat bizonyította (Williamson 1965; Junius 1996). Vizsgálatomban a Williamsonhipotézis függỏ változóját a gazdaságszerkezet regionális heterogenitásával helyettesítettem, amelyet az országos szerkezettől való vektoros módszerrel mért átlagos regionális eltéréssel azonosítottam. Az ötvenkét országra (lásd a Függeléket) kiterjedő vizsgálat összes forrásának felsorolásától terjedelmi korlátok miatt eltekintek, a három összevont gazdasági ágra vonatkozó regionális bruttó hozzáadott érték adatai Európa esetében az EUROSTAT-adatbázisból, a többi országnál többnyire a nemzeti statisztikai hivataloktól, a nemzeti bankoktól, illetve az ENSZ Human Development Reportjaiból származnak.

A számítások eredményét az 5. ábra mutatja. A legfontosabb megállapítás, hogy a gazdaságszerkezet regionális heterogenitása és az országok gazdasági fejlettségi szintje (GDP/fö vásárlóerő-paritáson) között szoros összefüggés mérhető. Mivel mindegyik vizsgált ország már elért bizonyos fejlettségi szintet (így a fordított-U bal oldali szárát keresztmetszeti vizsgálatban nem rekonstruálhatjuk), a fejlettség növekedésével folyamatos kiegyenlítödést tapasztalhatunk a régiók gazdasági szerkezete között, és kirajzolódni látszik egy új differenciálódási trend is a legfejlettebb gazdaságokban. Ugyanakkor a trendgörbétől való eltérés mértéke a fejlettség növekedésével egyre csökken.

Az ábra az egyes kontinensek-nagyrégiók adatait elkülönítve ábrázolja, ami további következtetések levonására is módot ad. Ázsia és Latin-Amerika esetében azonos fejlettségi szint mellett is jelentősen különbözỏ gazdaságszerkezeti egyenlỏtlenséggel találkozunk. Például Kína kiegyenlítettségével szemben (amelyet részben a régiók alacsony száma eredményez) Mongólia duális gazdasági szerkezete miatt a legheterogénebb a vizsgált országok közül. Mongóliában a szolgáltató föváros áll szemben az agrárjellegü vidékkel - mindkét esetben a vektoros módszer 
sajátosságából adódóan magas fokokban mért eltérésekkel. A fejlettebb Ázsiában érdekes tény, hogy Dél-Koreát a trendgörbéhez képest jelentősen magasabb gazdaságszerkezeti heterogenitás jellemzi. Latin-Amerikában a kiegyenlített Mexikóval és Bolíviával szemben egy heterogén Peru és Chile áll. A kelet-közép-európai volt szocialista országok a rendszerváltozás egyenlötlenségnövelö hatása ellenére a világtrendnél kiegyenlítettebbek, csak Oroszország és Szlovénia került e térségböl a trendgörbe fölé. Az európai összehasonlításban tapasztalható magas fokú heterogenitás tehát világösszefüggésekben alacsonynak minösül. A 15 régi EU-tagállam és Norvégia esetében a korábban megismert heterogén-mozaikos térszerkezet pedig világösszefüggésekben kiegyenlített viszonyokat takar.

\section{5. ÁBRA}

A gazdasági fejlettség és a regionális gazdaságszerkezeti egyenlötlenség összefüggése a világ országaiban az ezredfordulón.

(Relation of the Regional Inequalities of Development Level and the Structural

Heterogenity at the Millenium (World-wide sample)

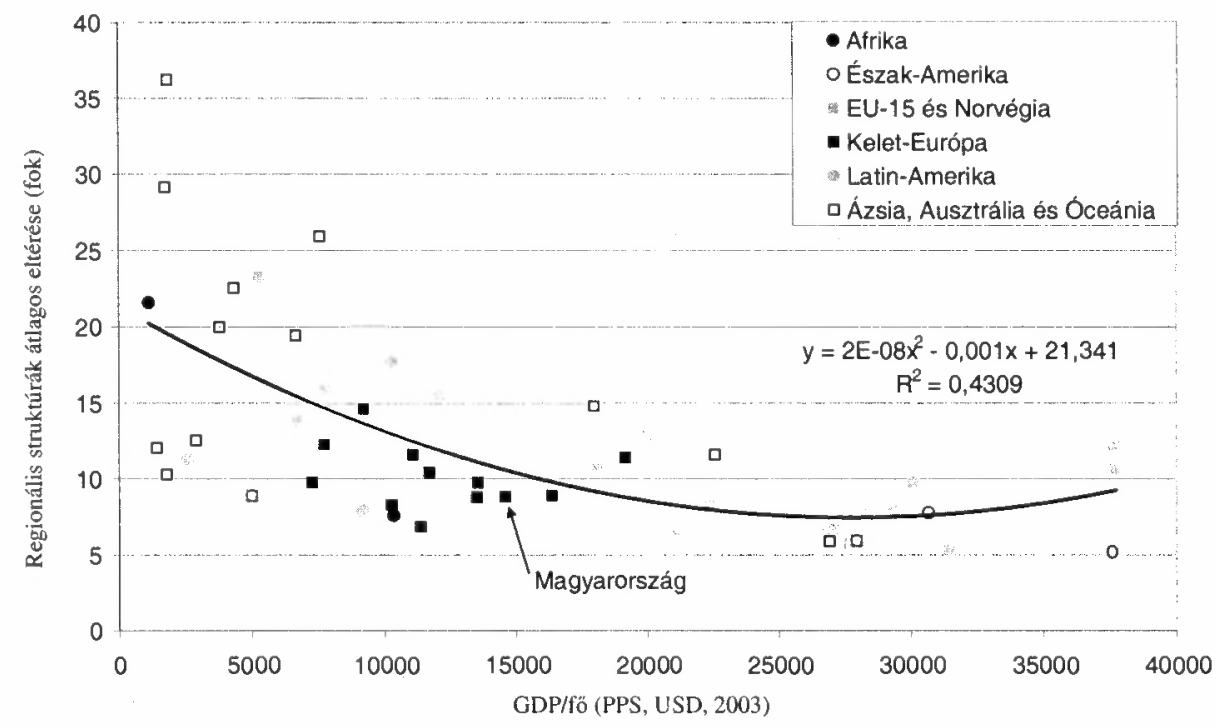

Forrás: Saját szerkesztés.

\section{Összefoglalás}

A strukturális vizsgálatok a területi kutatások egy jól elkülöníthető csoportját alkotják. A struktúravizsgálatok - nevükbỏl is adódóan - elsősorban (ágazati) szerkezeti közelítést alkalmaznak, de területi szempontok is különböző mértékben érvényesülnek bennük. A tanulmány a fogalommeghatározások mellett a szerkezetvizsgálati módszerek legfontosabb tulajdonságait elemezte, különös tekintettel a vektorszemléletǔ megközelítés előnyeire és hátrányaira. A magyarországi folyamatok európai és világösszefüggésekbe való helyezése alapján Magyarország megyéi 
gazdasági szerkezet szempontjából egymáshoz viszonylag hasonlóak, a különbségek inkább kisebbek a világ más, hasonló fejlettségü országával összevetve. Az európai szinten tapasztalható különbségek jól megmagyarázhatóak bizonyos közgazdasági okokkal (gazdasági szerkezetváltozás), és földrajzi-regionális tudományi modellekkel és problémacsoportokkal (centrum-periféria, szomszédsági hatás, lehatárolási hatás). A világ 52 országára kiterjedő empirikus vizsgálattal pedig a Williamsonhipotézis kiterjeszthetőségét sikerült igazolni a gazdasági szerkezet regionális heterogenitása és az országos gazdasági fejlettségi szint kapcsolatára.

\section{Irodalom}

Aiginger, K. (1999) Do industrial structures converge? - WIFO Working Papers. 116.

Aiginger, K.-Davies, S.W. (2004) Industrial Specialization and Geographic Concentration: Two Sides of the Same Coin? Not for the European Union. - Journal of Applied Economics. 2. 231-248. o.

Bickenbach, F.-Bode, E. (2006) Disproportionality Measures of Concentration, Specialization, and Polarisation. - Kiel Working Paper. 1276.

EUROSTAT Regio adatbázis

Frigyes E. (2000) Struktúra - koncentráció - egyenlötlenség. - Statisztikai Szemle. 8. 598-619. o.

Jeney L.-Szabó P. (2001) A magyar ipar változása a koncentrációs és specializációs indexek tükrében az 1990-es években. Földrajzi Konferencia, Szeged.

Junius, K. (1996) Economic Deleopment and Industrial Concentration: An Inverted U-Curve. - Kiel Working Paper. 770.

Kiss J. (1998) Az ágazati gazdaságszerkezet szerepe a regionális differenciálódásban Magyarországon. Tér és Társadalom. 1-2, 138-162. o.

Koszov, V.V. (1963) Vozmozsnüje resenyija problemi agregacii mezsotraszlevüh szvjazej - Voproszi Ekonomiki. 3.

KSH (2006) Magyarország nemzeti számlai. Budapest.

Liikanen, E. (1999) Strukturwandel und Anpassungsleistungen im europäischen verarbeitenden Gewerbe. Mitteilung der Kommission an den Rat, das Europäische Parlament, den Ausschuß der Regionen und den Wirtschafts- und Sozialausschuß.

Moore, J.H. (1978) A Measure of Structural Change in Output. - Review of Income and Wealth. 1. 105-118. o.

Nemes Nagy J. (1987) A regionális gazdasági fejlödés összehasonlító vizsgálata. Akadémiai Kiadó, Budapest.

Nemes Nagy J . (1998) A tér a társadalomkutatásban. Hilscher Rezső Szociálpolitikai Egyesület, Budapest.

Peters, H-R. (1988) Sektorale Strukturpolitik. R. Oldenbourg Verlag, München, Wien.

Probáld F. (1995) A regionális földrajz helye a geográfiában (háttérvázlat). - Regionális Tudományi Tanulmányok. 2. ELTE Regionális Földrajzi Tanszék.

Rechnitzer J. (1994) (szerk.) Fejezetek a regionális gazdaságtan tanulmányozásához. MTA RKK, Györ-Pécs.

Richardson, H.W. (1978) Regional Economics. University of Illinois Press, Urbana-Chicago-London.

Vikström, P. (2001) Long term Patterns in Swedish Growth and Structural Change. - Research Memorandum. GD-48. Groningen Growth and Development Centre.

Wacziarg, R. (2004) Structural Convergence. - CCDRL Working Papers. 8.

Williamson, J.G. (1965) Regional inequality and the process of national development: a description of the patterns. - Economic Development and Cultural Change. 4. 3-84. o. 
Függelék: A vizsgált országok föbb jellemzöi

Appendix: Main Indicators of the Analysed Countries (country, year, number of subnational entities, structural heterogenity - grade)

\begin{tabular}{|c|c|c|c|}
\hline Ország & 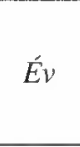 & $\begin{array}{l}\text { Rée } \\
\text { giók } \\
s z a ́- \\
m a\end{array}$ & $\begin{array}{c}\text { Átlagos } \\
\text { strukturá- } \\
\text { lis eltérés } \\
\text { (fok) }\end{array}$ \\
\hline Mongólia & 2002 & 5 & 36,21 \\
\hline Kirgizisztán & 2000 & 8 & 29,14 \\
\hline Thaiföld & 2004 & 20 & 25,94 \\
\hline Peru & 2000 & 24 & 23,31 \\
\hline Fülöp-szigetek & 2003 & 17 & 22,55 \\
\hline Mozambik & 1999 & 11 & 21,61 \\
\hline Sri Lanka & 2002 & 9 & 20,00 \\
\hline Kazahsztán & 2004 & 16 & 19,44 \\
\hline Chile & 2002 & 13 & 17,74 \\
\hline Brazília & 2003 & 27 & 15,94 \\
\hline Argentína & 2001 & 24 & 15,45 \\
\hline Dél-Korea & 2004 & 16 & 14,80 \\
\hline Orosz Föderáció & 2004 & 88 & 14,60 \\
\hline Kolumbia & 2003 & 24 & 13,85 \\
\hline Görögország & 2003 & 51 & 12,92 \\
\hline India & $\begin{array}{c}2001- \\
2002\end{array}$ & 32 & 12,52 \\
\hline Bulgária & 2003 & 28 & 12,27 \\
\hline Norvégia & 2003 & 19 & 12,13 \\
\hline Nepál & $\begin{array}{c}1998- \\
1999\end{array}$ & 5 & 12,03 \\
\hline Horvátország & 2003 & 21 & 11,60 \\
\hline Új-Zéland & 2003 & 15 & 11,60 \\
\hline Szlovénia & 2003 & 12 & 11,40 \\
\hline Bolívia & 2004 & 9 & 11,23 \\
\hline Portugália & 2003 & 30 & 10,62 \\
\hline Írország & 2002 & 8 & 10,56 \\
\hline Litvánia & 2003 & 10 & 10,40 \\
\hline
\end{tabular}

\begin{tabular}{|c|c|c|c|}
\hline Banglades & $\begin{array}{l}1999 \\
2000\end{array}$ & 20 & 10,33 \\
\hline Ausztria & 2003 & 35 & 9,77 \\
\hline Románia & 2003 & 42 & 9,77 \\
\hline Észtország & 2003 & 5 & 9,74 \\
\hline Csehország & 2003 & 14 & 8,90 \\
\hline Kína & 2003 & 31 & 8,88 \\
\hline Magyarország & 2003 & 20 & 8,84 \\
\hline Szlovákia & 2003 & 8 & 8,79 \\
\hline Lettország & 2003 & 6 & 8,29 \\
\hline Spanyolország & 2003 & 52 & 8,20 \\
\hline Mexikó & 2004 & 32 & 7,92 \\
\hline Hollandia & 2003 & 40 & 7,88 \\
\hline Belgium & 2003 & 43 & 7,84 \\
\hline Németország & 2003 & 439 & 7,83 \\
\hline Kanada & 2002 & 11 & 7,78 \\
\hline Finnország & 2003 & 20 & 7,70 \\
\hline $\begin{array}{l}\text { Dél-afrikai } \\
\text { Köztársaság }\end{array}$ & 2001 & 9 & 7,60 \\
\hline Lengyelország & 2003 & 45 & 6,86 \\
\hline Olaszország & 2003 & 103 & 6,67 \\
\hline Nagy-Britannia & 2003 & 133 & 6,59 \\
\hline Svédország & 2003 & 21 & 6,44 \\
\hline Japán & 2002 & 47 & 5,93 \\
\hline Ausztrália & $\begin{array}{l}2002- \\
2003\end{array}$ & 8 & 5,90 \\
\hline Franciaország & 2003 & 100 & 5,77 \\
\hline $\begin{array}{l}\text { Dánia } \\
\text { Amerikai }\end{array}$ & 2003 & 15 & 5,32 \\
\hline $\begin{array}{l}\text { Egyesült } \\
\text { Államok }\end{array}$ & 2004 & 51 & 5,20 \\
\hline
\end{tabular}




\section{REGIONAL STRUCTURAL INEQUALITIES}

\section{MÁRTON CZIRFUSZ}

In this paper the main aspects of structural researches in the regional studies and spatial analyses are presented. The article offers a concise summary of measuring structural change and lays emphasis on the strengths and weaknesses of the vector-based methodology first used by V. V. Kossov. We argue that this method can be widely used to measure regional structural inequalities within a country as well as in the world. Three important factors have been analysed which affect economic structural inequality among European regions: the homogenous geographical endowments, the inequality-raising economical transformation process and the modifiable areal unit problem. Based on an empirical study of regional inequalities of 52 countries in the world we show that the inverted U-curve pattern of the Williamson-Kuznets hypothesis can also be observed between the level of the development and the regional inequalities of economic structures measured by the sectoral GVA. 